\title{
GENETIC VARIABILITY WITHIN FUSARIUM SOLANI SPECIE AS REVEALED BY PCR-FINGERPRINTING BASED ON PCR MARKERS
}

\author{
Bereneuza Tavares Ramos Valente Brasileiro ${ }^{1}$; Maria Raquel Moura Coimbra ${ }^{4}$; Marcos Antonio de Morais Jr ${ }^{2,3}$; \\ Neiva Tinti de Oliveira ${ }^{1 *}$
}

${ }^{1}$ Departamento de Micologia, Universidade Federal de Pernambuco, Recife, PE, Brasil; ${ }^{2}$ Setor de Biologia Molecular/LIKA, Universidade Federal de Pernambuco, Recife, PE, Brasil; ${ }^{3}$ Departamento de Genética, Universidade Federal de Pernambuco. Recife, PE, Brasil; ${ }^{4}$ Departamento de Engenharia de Pesca, Universidade Federal Rural de Pernambuco, Recife, PE, Brasil.

Submitted: March 11, 2004; Returned to authors for corrections: July 07, 2004; Approved: September 27, 2004

\begin{abstract}
Fusarium solani fungus (teleomorph Haematonectria haematococca) is of relevance for agriculture, producing a disease that causes significant losses for many cultivars. Moreover, $F$. solani is an opportunistic pathogen to animals and humans. The complexity associated to its correct identification by traditional methods justifies the efforts of using molecular markers for isolates characterization. In this work, three PCR-based methods (one PCR-ribotyping and two PCR-fingerprinting) were used to investigate the molecular variability of eighteen F. solani isolates from four Brazilian States, collected from different substrates. Genetic analysis revealed the intraspecific variability within the $F$. solani isolates, without any correlation to their geographical origin and substrate. Its polymorphism was observed even in the very conserved sequence of rDNA locus, and the SPAR marker (GTG) $)_{5}$ showed the highest polymorphism. Together, those results may contribute to understand the relation between fungal genetic variability and cultivars resistance phenotypes to fungal-caused diseases, helping plant-breeding programs.
\end{abstract}

Key words: intron splice site, Fusarium solani, microsatellite, PCR-fingerprinting, ribosomal DNA

\section{INTRODUCTION}

The fungus Fusarium solani (teleomorph Haematonectria haematococca) is widely found in soil and constitutes one of the most important phytopatogen in agriculture. It infects cultivars like soybean (Glycine max), bean (Phaseolus vulgaris), cassava (Manihot esculenta), potato (Solanum tuberosum), among others $(11,12)$, causing rotteness of roots and fruits, wilting of the plant upper parts. As an opportunist pathogen, it can cause superficial mycoses in humans and animals $(5,18)$.

F. solani is sub-classified into formae specialis (phaseoli, pisi, cucurbitae, batatas, radicicola, robiniae, mori, piperis, eumartii, xanthoxyli, hibisci, lycopersici and phaseoli) based on host specificity $(19,20)$. Variations in the degree of virulence in formae specialis, as well as genetic diversity in isolates of different origins revealed that the Nectria haematococca-F. solani complex is composed by several phylogenetic species responsible for biologically distinct phytopathologies (10). Therefore, the knowledge of the genetic diversity within this pathogen specie should help to understand the causes of different disease manifestations.

In this sense, molecular tools based on DNA analysis are being currently used as an alternative to conventional morphological and biochemical tests for biotyping variants of many fungi species. The cluster of ribosomal DNA (Fig. 1), consisting of a tandem repeat of three coding $(18 \mathrm{~S}, 5.8 \mathrm{~S}$ and 28S) and two non-coding (Internal Transcribed Sequences-ITS and Intergenic Sequences-IGS) spacer regions (9), is a very informative locus for this kind of analysis. Due to its highly

*Corresponding author. Mailing address: Departamento de Micologia, Universidade Federal de Pernambuco. Av. Moraes Rego, s/n. 50670-901, Recife, PE, Brasil. Tel.: (+5581) 3271-8483. Fax: (+5581) 3271-8482. E-mail: nto@ufpe.br 


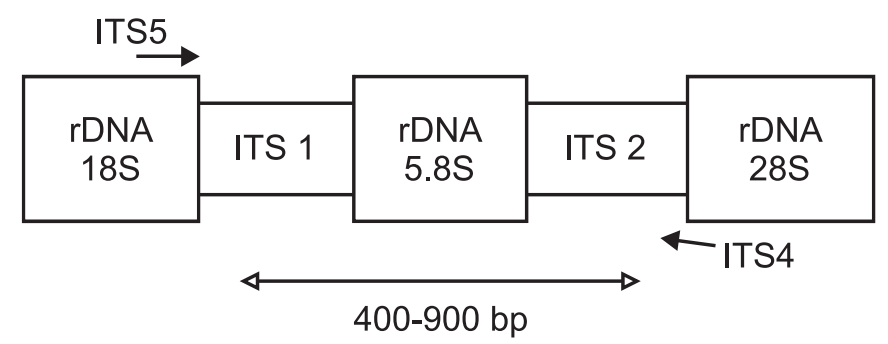

Figure 1. Schematic diagram of the fungal rDNA gene cluster. Genes encoding 18S, 5.8S and 28S ribosomal RNA subunits are separated by the internal transcribed sequences 1 (ITS1) and 2 (ITS2) that are spliced after transcription. The primers ITS4 and ITS5 (single-headed arrows) have been used to amplify this rDNA cluster from all fungi species so far, producing a species-specific fragment ranging from 400 to $900 \mathrm{bp}$ (double-headed arrow).

repetitive characteristic, but relative slow evolving rate, rDNA clusters are also subjected to inter-specific internal length and nucleotide variation $(17,21)$. Furthermore, restriction analysis of ITS amplicons enhances the potential of this systematic tool.

Besides rDNA markers, another PCR-based markers have shown to be very informative in discriminating fungal isolates. The introns have potentially high rates of sequence evolution and their analysis has become an important tool in studies of genome relatedness (4). Introns can be sorted out into four major categories (group I, group II, nuclear mRNA and nuclear tRNA) based on the splicing mechanisms (3). Group I introns in the small subunit rDNA have been found in a number of fungi (7) and the presence or absence of these introns caused length polymorphism of the small subunit rDNA 3' region of Fusarium solani (20). Additionally, another PCR-fingerprinting marker takes advantage on the use of microsatellite oligonucleotides that amplify genomic segments different from the repeat region itself. This approach, named Single Primer Amplification Reaction (SPAR), uses a single primer consisting of the core motif of microsatellites with repeat motifs, such as (CA)n, (CT)n, (GT)n, (GAC)n, (GTG)n, (GACA)n, (GATA)n, (TGTC)n, etc. These primers trigger site-specific annealing and initiates PCR amplification of genomic segments, which are flanked by inversely orientated and closely spaced repeat sequences (8). This method has been used to discriminate isolates of different fungi species, such as $S$. cerevisiae (8), F. oxysporum (1), Cenococcum geophilum (13), Phytophthora capsici (22) and Exophiala species (23).

The presence of different formae speciales associated to different degrees of pathogenicity and the complex taxonomy of $F$. solani justify efforts to genetically characterise this species in order to further develop an effective biocontrol strategy. The present report aimed to analyse different unrelated Brazilian isolates of $F$. solani based on PCR-fingerprinting methods.

\section{MATERIALS AND METHODS}

\section{Fungal strains}

Eighteen isolates of $F$. solani (Table 1) were provided by the mycological collection of the Department of Mycology, Federal University of Pernambuco (URM-UFPE). All strains were chosen according to their pathogen characteristics to different plants. The isolates were maintained in potato-dextrose-agar slants at $4^{\circ} \mathrm{C}$.

\section{DNA extraction}

Flasks containing $100 \mathrm{ml}$ Czapeck medium were inoculated with $3 \mathrm{ml}$ of $F$. solani conidial suspensions $\left(10^{6}\right.$ conidia/ml $)$ and incubated at $250 \mathrm{rpm}$ and $30^{\circ} \mathrm{C}$ for $96 \mathrm{~h}$. The mycelia were harvested by filtration, washed with sterile-distilled water and stored at $-20^{\circ} \mathrm{C}$ until use. For total genomic DNA was extracted, the mycelium was ground into the fine powder under liquid nitrogen and suspended in 800 mðl extraction buffer $(200 \mathrm{mM}$ Tris-HCl pH 8.0; 250 mM NaCl; 25 mM EDTA; $1 \%$ SDS). Upon homogenisation, the tubes were incubated for $15 \mathrm{~min}$ at $65^{\circ} \mathrm{C}$. DNA samples were purified with equal volumes of saturated phenol (1x), phenol:chloroform (1:1) mixture (1x) and chloroform:isoamyl alcohol (24:1) mixture (1x), and precipitated with $0.3 \mathrm{M} \mathrm{NaCl}$ and 2 volumes ethanol at $-20^{\circ} \mathrm{C}$ for $30 \mathrm{~min}$. The tubes were centrifuged at $12000 \mathrm{rpm}$ (SS4 rotor, Kubota, Japan) for 15 min and DNA pellets were rinsed with $70 \%$ ethanol, airdried, suspended in TE buffer (pH8.0) and stored at $4^{\circ} \mathrm{C}$ until use (14).

\section{PCR-ribotyping}

Amplification reactions were prepared to final volume of 25 mðl containing $1 \mathrm{x}$ Taq buffer $(20 \mathrm{mM}$ Tris- $\mathrm{HCl} \mathrm{pH} 8.4,50 \mathrm{mM}$ $\mathrm{KCl}), 50 \mathrm{ng}$ template DNA, $1.5 \mathrm{mM} \mathrm{MgCl}_{2}, 0.2 \mathrm{mM} \mathrm{dNTP}, 12.5$ pmols of each ITS4 (5'-TCCTCCGCTTATTGATATGC-3') and ITS5 (5'-GGAAGTAAAAGTCGTAACAA-3') and 1.25 U Taq DNA polymerase (Operon Technologies, CA), as described by White et al. (21). Thermal cycling consisted of initial denaturation of 4 minutes at $95^{\circ} \mathrm{C}$, followed by 40 cycles of 1 minute at $92^{\circ} \mathrm{C}, 1$ minute at $55^{\circ} \mathrm{C}$ and 2 minutes at $72^{\circ} \mathrm{C}$, with 5 minutes at $72^{\circ} \mathrm{C}$ for final extension. Amplification products were visualized in $1 \%(\mathrm{w} / \mathrm{v})$ agarose gel at $3 \mathrm{~V} / \mathrm{cm}^{-1}$ in TBE buffer (pH8.0) after ethidium bromide staining.

Aliquots of $4 \mu \mathrm{l}$ of the amplicons were subjected to enzymatic digestion with DraI, EcoRI, HaeIII or MspI, according to manufacturer instructions. Fragments were separated in $1.4 \%$ (w/ v) agarose gels and their molecular weights were determined using to 50-bp ladder marker (Invitrogen). Polyacrilamyde gel electrophoresis was performed according to Sambrook et al. (16).

\section{PCR-Fingerprinting}

Fingerprinting analysis were performed with EI1 Type I Intron Splice Site primer (5'-CTGGCTTGGTGTATGT-3') (4) and 
Table 1. Geographical origin, sampling substrate and ribotyping of Fusarium solani isolates.

\begin{tabular}{|c|c|c|c|c|c|c|c|}
\hline \multirow{2}{*}{ Isolates $^{a}$} & \multirow{2}{*}{$\begin{array}{l}\text { Access } \\
\text { number }^{\mathrm{b}}\end{array}$} & \multirow{2}{*}{$\begin{array}{l}\text { Geographical } \\
\text { origin }\end{array}$} & \multirow{2}{*}{ Substrate } & \multirow{2}{*}{ ITS (bp) } & \multicolumn{3}{|c|}{ ITS-RFLP (bp) } \\
\hline & & & & & EcoRI & $M s p \mathrm{I}$ & HaeIII \\
\hline 1 & 1709 & Pernambuco & Air & 620 & $310(x 2)$ & $380+240$ & $250(x 2)+120$ \\
\hline 2 & 2143 & Santa Catarina & Araucaria excelsa & 600 & $300(x 2)$ & $460+140$ & $340+150+110$ \\
\hline 3 & 2391 & Pernambuco & Arachis hypogaea & 620 & $310(x 2)$ & $380+240$ & $250(x 2)+120$ \\
\hline 4 & 2429 & Pernambuco & Foliage & 620 & $310(x 2)$ & $380+240$ & $250(x 2)+120$ \\
\hline 5 & 2490 & Pernambuco & Foliage & 620 & $310(x 2)$ & $380+240$ & $250(x 2)+120$ \\
\hline 6 & 2696 & Pernambuco & Lycopersicom esculentum & 620 & $310(x 2)$ & $380+240$ & $250(x 2)+120$ \\
\hline 7 & 3088 & São Paulo & Albertia myrcifolia leaves & 620 & $310(x 2)$ & $380+240$ & $250(x 2)+120$ \\
\hline 8 & 3105 & São Paulo & Rudigea gardenoides leaves & 620 & $310(x 2)$ & $380+240$ & $250(x 2)+120$ \\
\hline 9 & 3338 & São Paulo & Vermonia herbacea rhyzosphere & 620 & $310(x 2)$ & $380+240$ & $250(x 2)+120$ \\
\hline 10 & 3472 & São Paulo & Vermonia herbacea rhyzosphere & 620 & $310(x 2)$ & $380+240$ & $250(x 2)+120$ \\
\hline 11 & 3821 & Pernambuco & Soil & 620 & $310(x 2)$ & $380+240$ & $250(x 2)+120$ \\
\hline 12 & 3838 & Pernambuco & Soil & 620 & $310(x 2)$ & $380+240$ & $250(x 2)+120$ \\
\hline 13 & 4050 & Pernambuco & Interdigital feet scale & 620 & $310(x 2)$ & $380+240$ & $250(x 2)+120$ \\
\hline 14 & 4054 & Pernambuco & Interdigital feet scale & 620 & $310(x 2)$ & $380+240$ & $250(x 2)+120$ \\
\hline 15 & 4055 & Pernambuco & Interdigital feet scale & 620 & $310(x 2)$ & $380+240$ & $250(x 2)+120$ \\
\hline 16 & 4059 & Pernambuco & Interdigital feet scale & 620 & $310(x 2)$ & $380+240$ & $250(x 2)+120$ \\
\hline 17 & 4098 & Bahia & Passiflora edulis seeds & 620 & $310(x 2)$ & $380+240$ & $250(x 2)+120$ \\
\hline 18 & 2121 & Santa Catarina & Allium сера & 620 & $310(x 2)$ & $380+240$ & $250(x 2)+120$ \\
\hline
\end{tabular}

${ }^{\mathrm{a}}$ Isolate number considered in this paper; ${ }^{\mathrm{b}}$ Access number according to Mycological collection Micoteca-URM (Recife, Brazil).

the $(\mathrm{GTG})_{5}$ single primer $(8)$ by amplification reactions improved in our laboratory. For the first primer, the amplification reactions contained 1x Taq buffer, $50 \mathrm{ng}$ of template DNA, $3 \mathrm{mM} \mathrm{MgCl}_{2}$, $0.25 \mathrm{mM}$ dNTP, 25 pmols of EI1 primer and 1.25 U Taq DNA polymerase (Operon Technologies, CA) into final volume of 25 $\mu 1$. Thermal cycling consisted of an initial denaturation of 3 minutes at $94^{\circ} \mathrm{C}$, followed by 40 cycles of 1 minute at $94^{\circ} \mathrm{C}, 2$ minute at $45^{\circ} \mathrm{C}$ and 90 seconds at $74^{\circ} \mathrm{C}$, with to final extension of 5 minutes at $74^{\circ} \mathrm{C}$. For the second primer, the amplification reactions contained 1x Taq buffer, 50 ng of template DNA, 1.5 $\mathrm{mM} \mathrm{MgCl}_{2}, 0.25 \mathrm{mM}$ dNTP, 25 pmols of $(\mathrm{GTG})_{5}$ primer and 1.25 $\mathrm{U}$ of Taq DNA polymerase (Operon Technologies, CA) to $25 \mu \mathrm{l}$ final volume. Thermal cycling consisted of an initial denaturation of 5 minutes at $93^{\circ} \mathrm{C}$, followed by 40 cycles of 20 seconds at $93^{\circ} \mathrm{C}, 45$ seconds at $55^{\circ} \mathrm{C}$ and 90 seconds at $72^{\circ} \mathrm{C}$, with 6 minutes at $72^{\circ} \mathrm{C}$ for final extension. The Amplicons were visualised in $1 \%(\mathrm{w} / \mathrm{v})$ agarose gel at $3 \mathrm{~V} / \mathrm{cm}^{-1}$ in TBE buffer (pH8.0) after ethidium bromide staining.

\section{Genetic analysis}

The variable binary similarity matrix was prepared using Jaccard coefficient by the NTSYS (Numerical Taxonomy System of multivariate program) computer program version pc2.1 (15). Dendrograms were prepared by UPGMA (Unweighted Pair Group Method with Arithmetical average) analysis.

\section{RESULTS AND DISCUSSION}

Amplification of the small subunit ribosomal DNA ITS15.8S-ITS2 (ITS) produced one fragment of 620-bp for all $F$. solani isolates (ITS-type I), except for the isolates 2143 and 4098, for which a single band of approximately 600-bp (ITStype II) was obtained (Table 1). These results were later confirmed by running the amplicons in $6 \%$ polyacrilamide gel that allows higher definition between fragments that differs by few base pairs. These results suggested a possible length polymorphism for that sequence among different isolates of this species, which was further corroborated by digesting the amplification products with restriction enzymes (Table 1). No digestion at all was observed for DraI, while EcoRI produced a double monomorphic fragment of approximately 310-bp for ITS-type I and a 300-bp for ITS-type II isolates. Digestion with $M s p$ I produced DNA fragments of 380-bp and 240-bp for all isolates ITS-type I, and DNA fragments of 460bp and 140-bp for ITS-type II isolates. These two isolates also produced HaeIII restriction fragments different from the standard profile of 250-bp and 120-bp fragments. Restrictions with the last two enzymes showed polymorphism in both number and length of the resulting fragments and support the idea of an intraspecific genetic diversity among different isolates of $F$. solani. 
These results are supported by previous studies on the genetic diversity found for this species complex, as observed by Edel et al. (6) after digesting ITS amplicons of different isolates of $F$. solani with $M s p I$. On the other hand, other reports failed to detect genetic polymorphism after digesting ITS amplicons of different isolates of $F$. solani with HaeIII $(2,10)$. Nevertheless, rDNA intergenic spacer (IGS) digested with MspI also showed fragment polymorphism among different $F$. solani isolates (9). Taking it into account, all these information reinforce the genetic complexity of the specie $F$. solani complex.

Further investigations on the intraspecific polymorphism used both low-variable intron splice site marker and highvariable SPAR marker. The Fig. 2 shows the amplification profile of the $F$. solani isolates using the intron splice site, which varied from 7 to 13 fragments ranging from 250-bp to 3500-bp. Clustering analysis (data not shown) showed that isolates 3088, 3105, 3472, 3821 and 3838 presented the same amplification profile with $100 \%$ similarity, comprising the EI1-group 1, which could represent a clonal lineage. The isolates 3338 and 4054 shared $80-85 \%$ similarity with the EI1-group 1 pattern, while isolates 2391 and 4050 showed only $50 \%$ of similarity. The level of

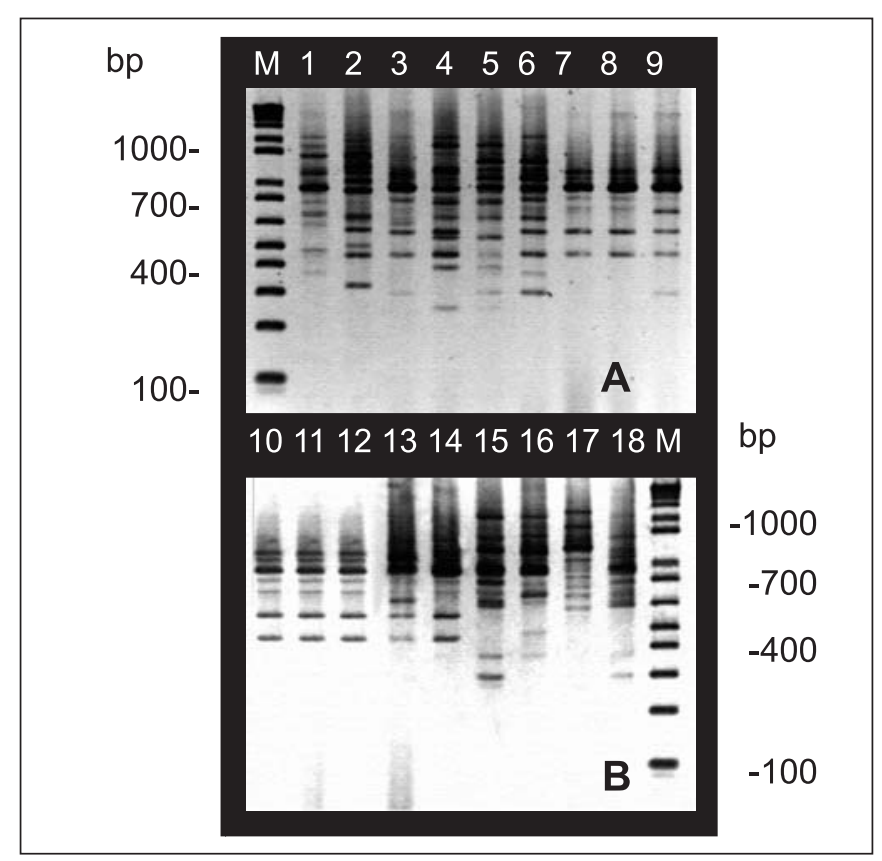

Figure 2. DNA fingerprinting of Fusarium solani isolates by using intron splice site primer EI1. (A) Lanes 1-9 represent the amplification products of the isolates 1709, 2143, 2391, 2429, 2490, 2696, 3088, 3105 and 3338, respectively. (B) Lanes 10-17 represent the amplification products of the isolates 3472,3821 , 3838, 4050, 4054, 4055, 4059 and 4098, respectively. Lane 18: isolate 2121 (F. solani var. minus). M: 1-Kb ladder. similarity lied between 50 to $60 \%$ for the other isolates. Isolates 2143 and 4098 showed the highest genetic divergence for the EI1 primer, as detected by the ITS analysis.

The type I intron sequences were detected in the 3' region of the small subunit rDNA (18S gene) of different formae speciales of $F$. solani (20). These authors reported length polymorphism of the intron sequences inside the $18 \mathrm{~S}$ gene, although it has been a consensus that this region may evolve slowly among distantly related organisms. Therefore, it suggests that isolates 2143 and 4098 contain significant genomic differences that highlight the genetic complexity of this species. To our knowledge, this is the first report on the use of the primer EI1 for fingerprinting analysis of Fusarium.

The amplification with $(\mathrm{GTG})_{5}$ primer showed fingerprinting patterns containing 7 to 16 reproducible fragments, ranging from 500-bp to 3500-bp (Fig. 3). This primer was able to discriminate all $F$. solani isolates analyzed, including those of

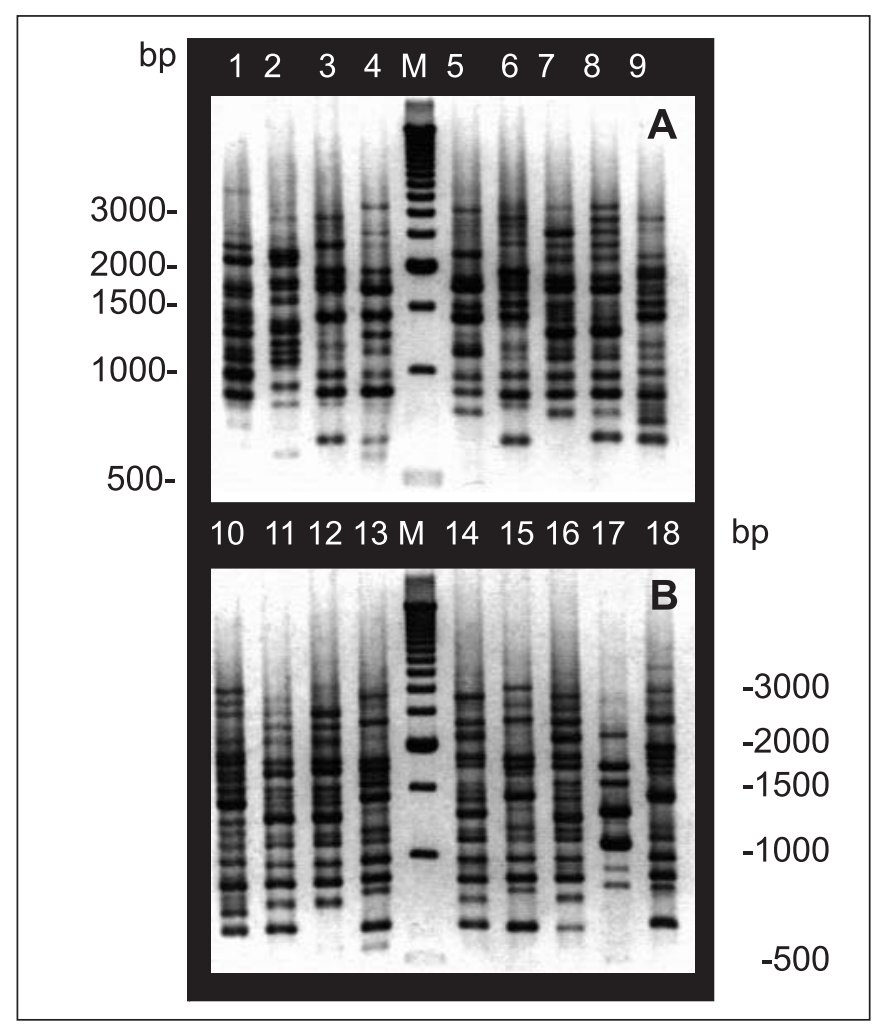

Figure 3. DNA fingerprinting of Fusarium solani isolates by using the SPAR (GTG)5. (A) Lanes 1-9 represent the amplification products of the isolates 1709, 2143, 2391, 2429, 2490, 2696, 3088, 3105 and 3338, respectively. (B) Lanes 10-17 represent the amplification products of the isolates 3472,3821 , 3838, 4050, 4054, 4055, 4059 and 4098, respectively. Lane 18: isolate 2121 (F. solani var. minus). M: 500-pb ladder. 
the EI1-group 1. Again, isolates 2143 and 4098, together with isolates 3821 and 3838, showed the highest genetic diversity compared to the others isolates (data not shown), thus emphasizing their genomic divergence. Barve et al. (1) reported that $(\mathrm{AGT})_{5},(\mathrm{ATC}) 5$ and (GATA) $)_{4}$, among 13 other SPARs tested, were able to discriminate isolates of four different races of $F$. oxysporum f. sp. ciceri. The present paper describes the first report on the use of the (GTG $)_{5}$ to analyse intraspecific genetic diversity of the $F$. solani. Together, both intron splice site and SPAR analysis may contribute to understand the genetic complexity of this species.

A combinatory clustering analysis used all three PCR markers and revealed the genetic relatedness among the isolates (Fig. 4). Indeed, as shown for PCR-ribotyping, isolates 2143 and 4098 were the most divergent isolates in our analysis producing two phenetic groups. The third group was composed by the isolate 2121 and 15 other isolates, although it presented similarity level below $70 \%$ for most of isolates. The fact that 2121 has been originally classified as $F$. solani var. minus suggests that our analysis can be used for $F$. solani variety and/or formae specialis discrimination. SPAR primers have been postulated for variability studies within the $F$. oxysporum $\mathrm{f}$. sp. ciceri races, where the race 3 represented the most distinct group of the taxon with $26.7 \%$ of similarity to others races (1). Therefore, it is plausible to speculate that the isolates 2143 and 4098, showing only $30 \%$ similarity between them and $25 \%$ similarity to other isolates analyzed here, may compose two subspecies group (races or varieties) of $F$. solani. Unfortunately, no correlation

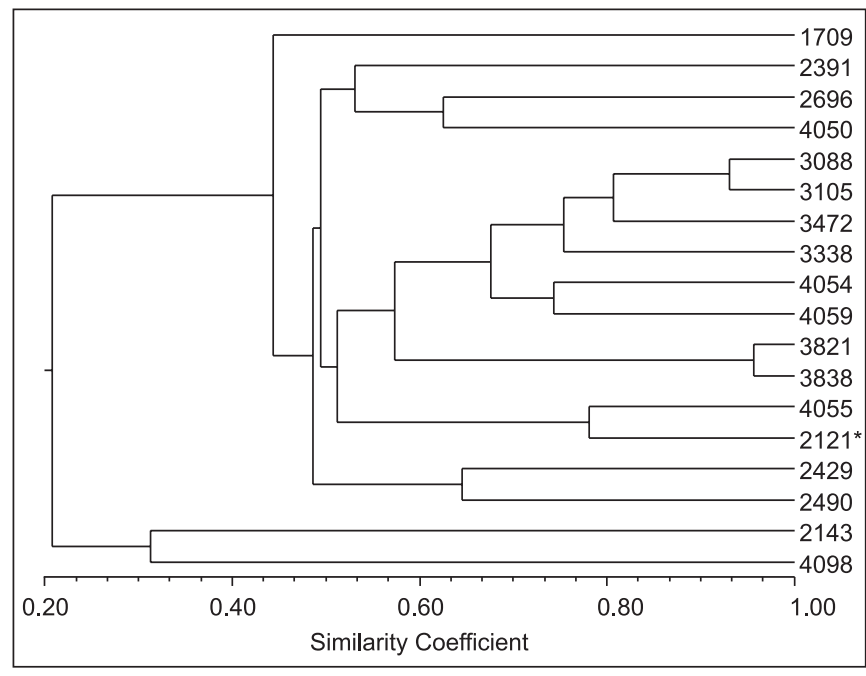

Figure 4. Combinatory clustering analysis of the $18 \mathrm{~F}$. solani isolates using all the PCR markers used in this work. The asterisk represents the strain 2121 of $F$. solani var. minus. Similarity matrix was prepared using Jaccard coefficient to generate a dendrogram by UPGM. was found with geographical origin of the isolates and their genetic relatedness in this study.

The results reported here point out $(\mathrm{GTG})_{5}$ primer as a reliable method for detecting genetic differences between isolates of $F$. solani, as it has been postulated for other fungi species $(8,13,23)$, while ITS and EI1 primers are more useful for clonal analysis. Similarly, results of our laboratory on the fingerprinting of $S$. cerevisiae isolates showed that EI1 primer was poorly informative for yeast strain identification, whereas $(\mathrm{GTG})_{5}$ primer unequivocally discriminate genetic strains (data not shown).

Our study concluded that $F$. solani isolates might compose a highly genetically variable species that could be related to its wide range of hosts. Therefore, understanding the relation between fungal variability and plant resistance phenotype may help driving the progress of breeding programs or the use of recombinant DNA technology towards producing resistant cultivars.

\section{ACKNOWLEDGEMENTS}

The authors wish to thank the Mycological collection Micoteca-URM, Federal University of Pernambuco, Recife, for kindly providing $F$. solani isolates. The Brazilian funding Agencies CAPES and CNPq supported this work.

\section{RESUMO}

\section{Variabilidade genética em espécies de Fusarium solani revelada pela técnica de impressão genética baseada em marcadores PCR}

O fungo Fusarium solani (teleomorfo Haematonectria haematococca) apresenta uma expressiva importância na agricultura por ser considerado patógeno para várias culturas de interesse econômico causando doença conhecida por podridão das raízes, além de ser patógeno aos animais e ao homem, provocando nestes últimos, micoses superficiais e sistêmicas. A complexidade associada a sua identificação correta através de métodos tradicionais justifica os esforços de usar marcadores moleculares para caracterização dos isolados. Neste trabalho, três métodos baseados na tecnologia da PCR (um por ribotipagem por PCR e dois por impressão genética por PCR) foram utilizados para investigar a variabilidade molecular de dezoito isolados de $F$. solani de quatro Estados brasileiros, coletados de diferentes substratos. A análise genética revelou a variabilidade intraespecífica dos isolados de $F$. solani, sem qualquer correlação para a origem geográfica e substrato. Seu polimorfismo foi observado até mesmo na sequiência conservada do locus do rDNA, e o marcador SPAR (GTG) mostrou o mais alto polimorfismo. Em conjunto, estes resultados poderão auxiliar nos estudos da relação entre variabilidade do 
perfil genético de isolados e os fenótipos de resistência de determinados cultivares às doenças provocadas pelo fungo, orientando programas de melhoramento vegetal.

Palavras-chave: DNA ribossomal, intron splice site, Fusarium solani, impressão genética por PCR, microssatélite.

\section{REFERENCES}

1. Barve, M.P.; Haware, M.P.; Sainani, M.N.; Ranjekar, P.K.; Gupta, V.S. Potential of microsatellites to distinguish four races of Fusarium oxysporum f. sp. ciceri prevalent in India. Theoretic Appl. Genet., 102:138-147, 2001.

2. Bateman, G.L.; Kwasna, H.; Ward, E. Relationships among Fusarium spp. estimated by comparing restriction fragment length polymorphisms in polymerase chain reaction-amplified nuclear rDNA. Can. J. Microbiol., 42:1232-1240, 1996.

3. Cech, T.R. Self-splicing of group I-introns. Ann. Rev. Biochem., 59:543-568, 1990.

4. De Barros Lopes, M.; Soden, A.; Henschke, P.A.; Langridge, P. PCR differentiation of commercial yeast strains using intron splice site primers. Appl. Environ. Microbiol., 62:4514-4520, 1996.

5. Dijk, C.T.; Vats, T.S.; Berg, W.H.; Landwehr, A.J. Fusarium solani infection of a hipertensive leg ulcer in a diabetic. Mykosen, 23:603606, 1980.

6. Edel, V.; Steinberg, C.; Galtheron, N.; Alabouvette, C. Evaluation of restriction analysis of polymerase chain reaction (PCR) - amplified ribosomal DNA for identification of Fusarium species. Mycol. Res., 101:179-187, 1996.

7. Hibbert, D.S. Phylogenetic evidence for horizontal transmission group I introns in the nuclear ribossomal DNA of mushroom-forming fungi. Mol. Biol. Evol., 13:903-917, 1996.

8. Lieckfeldt, E.; Meyer, W.; Börner, T. Rapid identification and differentiation of yeasts by DNA and PCR fingerprinting. J. Basic Microbiol., 33:413-426, 1993.

9. Miller, R.N.G.; Quezado-Soares, A.M.; Lopes, C.A. Molecular comparison of Fusarium populations causing eumartii wilt and dry rot of potato in Brazil. Fitopatol. Bras., 24:149-155, 1999.

10. O'Donnell, K. Molecular phylogeny of the Nectria haematococca Fusarium solani species complex. Mycologia, 92:919-938, 2000.
11. Oliveira, V.C. de; Costa, J.L.S. Restriction analysis of rDNA (ARDRA) can differentiate Fusarium solani f. sp. phaseoli from F. solani $\mathrm{f}$. sp. glycines. Fitopatol. Bras., 27:631-634, 2002.

12. Poltronieri, L.S.; Trinidad, D.R.; Albuquerque, F.C.; Duarte, M.L.R.; Cardoso, S.S. Incidence of Fusarium solani in annulled in the State of Pará, Brazil. Fitopatol. Bras., 27:544, 2002.

13. Portugal, A.; Martinho, P.; Vieira, R.; Freitas, H. Molecular characterization of Cenococcum geophilum isolates from na ultramafic soil in Portugal. South African J. Sci., 97:617-619, 2001.

14. Raeder, U.; Broda, P. Rapid preparation of DNA filamentous fungi. Lett. Appl. Microbiol., 1:17-20, 1985

15. Rohlf, F.J. NTSYS-PC Numerical taxonomy and multivariate analysis system. Applied Biostatistics, lnc. New York, Exeter Publishing, 1988.

16. Sambrook, J.; Fristsch, E.F.; Maniats, T. Molecular cloning a laboratory manual. $2^{\mathrm{a}}$ ed. Cold Spring Harbor Laboratory. Cold Spring Harbor: New York, 1989.

17. Samuels, G.J. Seifert, K.A. The impact of molecular characters on systematics of filamentous ascomycetes. Ann. Rev. Phytopathol., 33:37-67, 1995.

18. Stover, R.H. Fusarium diseases in the tropics. In: Nelson PE, Toussoun TA, Cook RJ Fusarium: Diseases, biology, and taxonomy. Pennsylvania: The Pennsylvania State University Press, 1981, pp 114-120.

19. Suga, H.; Hasegawa, T.; Mitsui, H.; Kageyama, K.; Hyakumachi, M. Phylogenetic analysis of the phytopathogenic fungus Fusarium solani based on the rDNA-ITS region. Mycol. Res., 104:11751183, 2000a.

20. Suga, H.; Oyabu, K.; Ito, M.; Kageyama, K.; Hyakumachi, M. Detection of intron-like sequences in the small subunit rDNA 3'region of Fusarium solani. Mycol. Res., 104:782-787, 2000b.

21. White, T.J.; Bruns, T.; Lee, S.; Taylor, J. Amplification and direct sequencing of fungal ribosomal RNA genes for phylogenetics. In: Innis, M.A.; Gelfand, D.H.; Sninsky, J.J.; White, T.J. (Ed.) PCR Protocols, a guide to methods and applications. New York. Academic Press, 1990, pp.315-322.

22. Youn, C.H.; Jin, J.H. Estimation of genetic variation of Korean isolates of Phytophthora capsici by using molecular markers. Mycobiology, 29:43-47, 2001.

23. Youn, C.H.; Kyoung, K.Y. Molecular analysis of Exophiala species using molecular markers. Mycobiology, 30:1-4, 2001. 